POLLACK PERIODICA

An International Journal for Engineering and Information Sciences

DOI: $10.1556 / 606.2016 .11 .1 .11$

Vol. 11, No. 1, pp. 113-127 (2016)

www.akademiai.com

\title{
SIMULATION-SUPPORTED DESIGN OF A HUNGARIAN NATIONAL SPORTS CENTER
}

\author{
${ }^{1}$ Bálint BARANYAI, ${ }^{2}$ Bálint BACHMANN, ${ }^{3}$ István KISTELEGDI \\ 1, 2, 3 Faculty of Engineering and Information Technology, University of Pécs \\ Boszorkány u. 2, H-7624 Pécs, Hungary \\ e-mail: ${ }^{1}$ baranyaibalint@gmail.com, ${ }^{2}$ bachmann@pmmk.pte.hu, \\ ${ }^{3}$ kistelegdisoma@pmmik.pte.hu
}

Received 1 January 2015; accepted 16 September 2015

\begin{abstract}
Getting the possibility to participate in an actual design process of a Hungarian national sports center is a unique chance to demonstrate and investigate the potential of the dynamic simulation supported building design research program. The research is based on synchronous energy simulations and architectural planning. Energetic and climatic simulations are made during the whole design process. All possible simulated building climate- and energy parameters of the planned versions are compared to each other. In this way it is possible continuously develop the energy and climate characteristic of the designed building. The goal is to reach an accurate design method to be able to predict and minimize the total energy needs of the building as early as the design stage. In the first phase of this process the simulation models of the plan variations are compared, which helps to locate the possible weaknesses of the proposed building geometry and structures or its setting method to develop he building structures and proposed building services systems. In the second phase the chosen building plan is optimized and quantified by final simulations.
\end{abstract}

Keywords: Dynamic building climate and energy simulation, Synchronous energy simulation and architectural planning

\section{Model variations}

After defining the exact geological site and the plan's layout, a weather profile is loaded that was generated from the 'Meteonorm' climate data bank. It represents 5-year average weather data in hourly resolution (Fig. 1-Fig. 3).

In the design process there has been three different basic architectural layouts. The $1^{\text {st }}$ was - one can say - a conventional sports hall in terms of geometry and materials. 

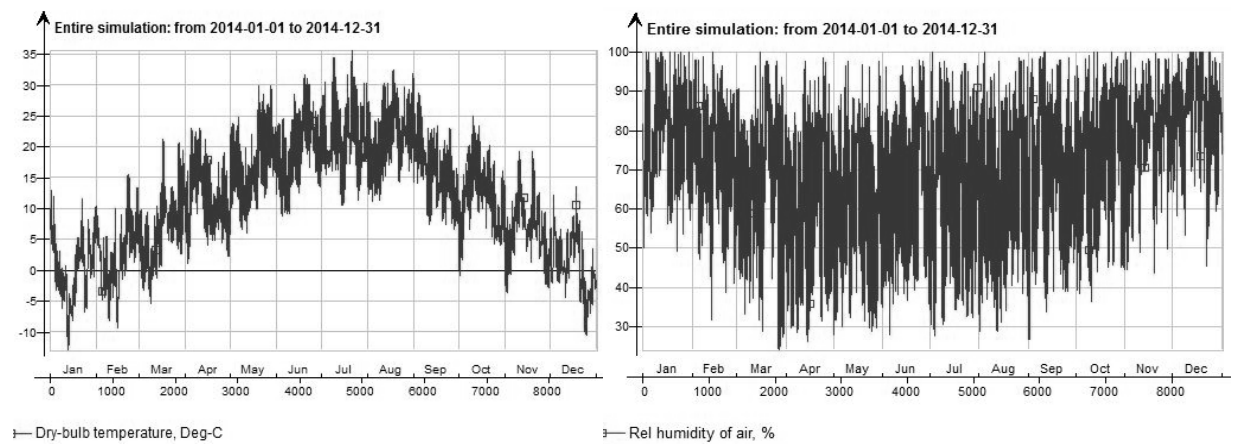

Fig. 1. The loaded annual $(8760 \mathrm{~h})$ weather data-dry-bulb temperature $\left[\mathrm{C}^{\circ}\right]$ and relative humidity [\%] of air (Meteonorm 7.0)
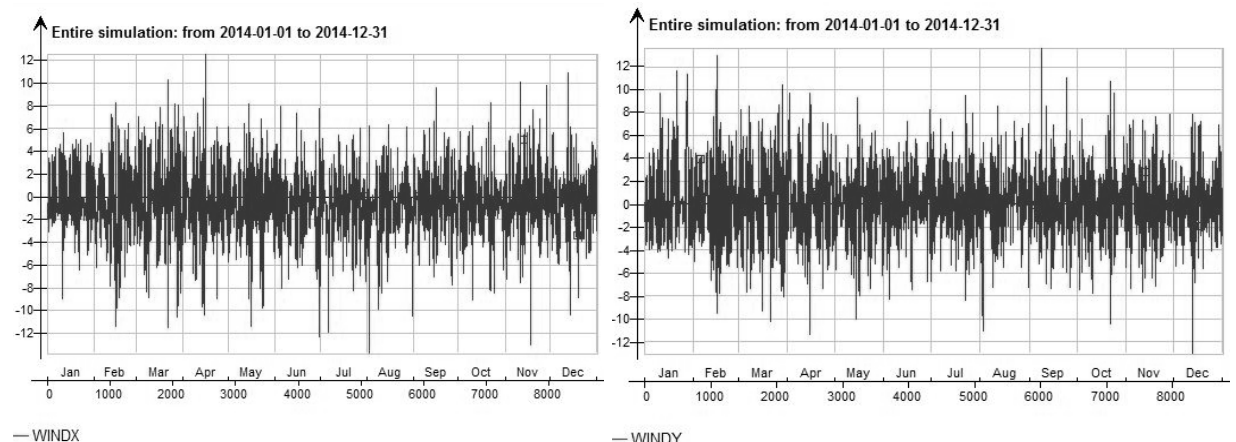

Fig. 2. The loaded annual $(8760 \mathrm{~h})$ weather data - wind speed [m/s] and wind direction (Meteonorm 7.0)
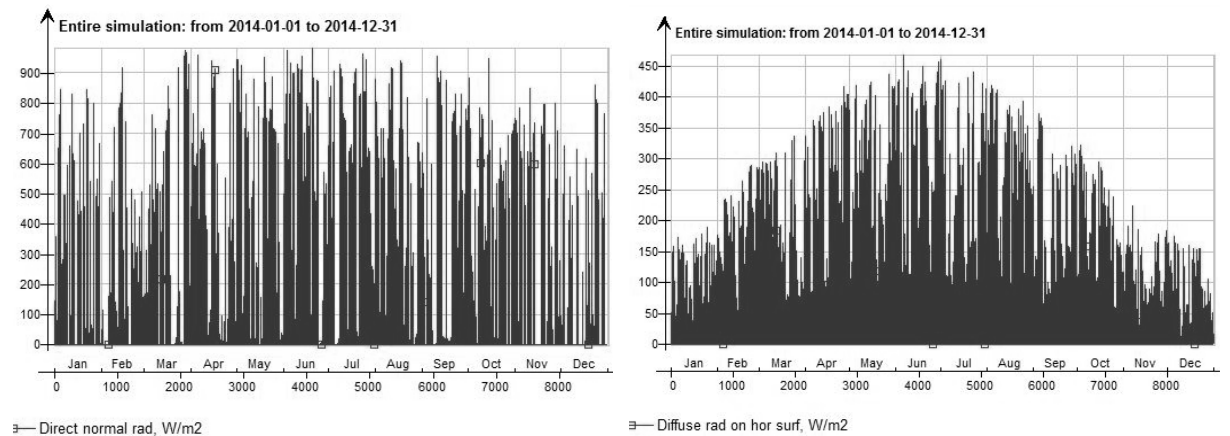

Fig. 3. The loaded annual $(8760 \mathrm{~h})$ weather data - direct solar radiation $\left[\mathrm{W} / \mathrm{m}^{2}\right]$ and diffuse solar radiation $\left[\mathrm{W} / \mathrm{m}^{2}\right]$ (Meteonorm 7.0)

The team was involved at the $2^{\text {nd }}$ version (Fig. 4), which main invention was the use of a huge translucent polycarbonate roof-light on top, rather than standard side windows in the façade walls. The plan consisted of four 3-storey-high solid towers on each corner

Pollack Periodica 11, 2016, 1 
of the building. All the services were placed in those towers. The main hall was capable to accommodate 3 normal size basketball courts, which can be separated by mobile walls. The main hall is also equipped with mobile viewing area surrounding the main court.
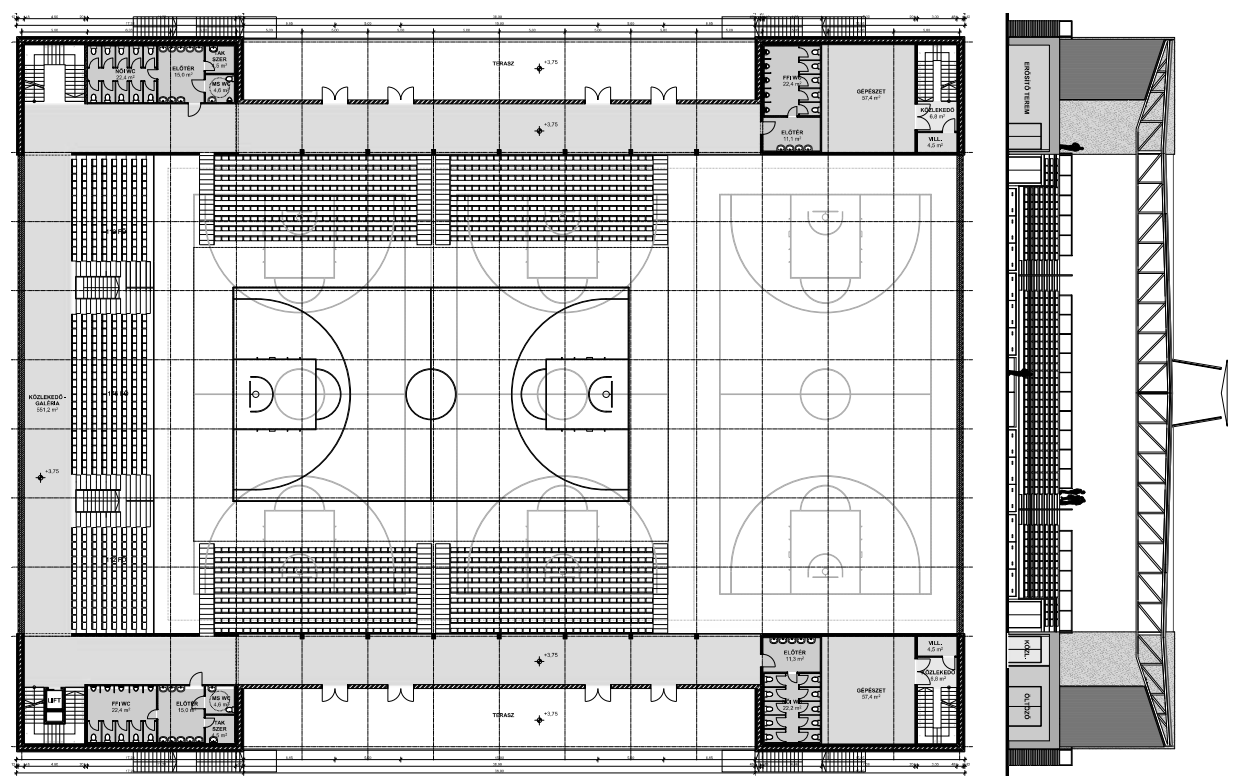

Fig. 4. The 1st simulated model is the $2^{\text {nd }}$ architectural version - floor plan and cross section

\section{Dynamic calculation of the basic architectural concept}

The dynamic simulation supported building design research program is based on synchronous thermal energy simulations and architectural planning. For thermal climate and energy building behavior prediction thermal simulations are today's most developed and adequate tools with appropriate level of accuracy [1], [2]. The annual energetic and climatic performance of the models was compared with the dynamic simulation program IDA ICE 4.5, in hourly resolution. For comparison of the roof-light concept a reference model was used with only side windows on all the four façades without any skylight and equipped exclusively with mechanical ventilation. In comparison the first conceptual model of the $2^{\text {nd }}$ architectural layout contained double layer cavity roof with polycarbonate skylight in each layer, the same surface size as the reference model's side windows and equipped with a combination of mechanical and natural ventilation.

The annual simulation results show that from spring till autumn there is an order of magnitude difference between the two, in terms of day-lighting (measured in Lux) for the benefit of the roof-light model. The thermal comfort in the summer is also better in the conceptual mode, although the diagram is not so uniform as in the reference model, 
where the mechanical cooling and ventilation alone - meaning, without natural ventilation - couldn't cope with the overheating.

The energy results also reflect the before mentioned difference. The cooling energy consumption is almost 3-times more in the reference model and the energy demand used for mechanical ventilation is also much higher. The reference model has a marginal advantage only in the heating energy consumption thanks to its better insulation performance and less heat loss of the roof structure thanks to the lack of polycarbonate (Fig. 5 - Fig. 7).
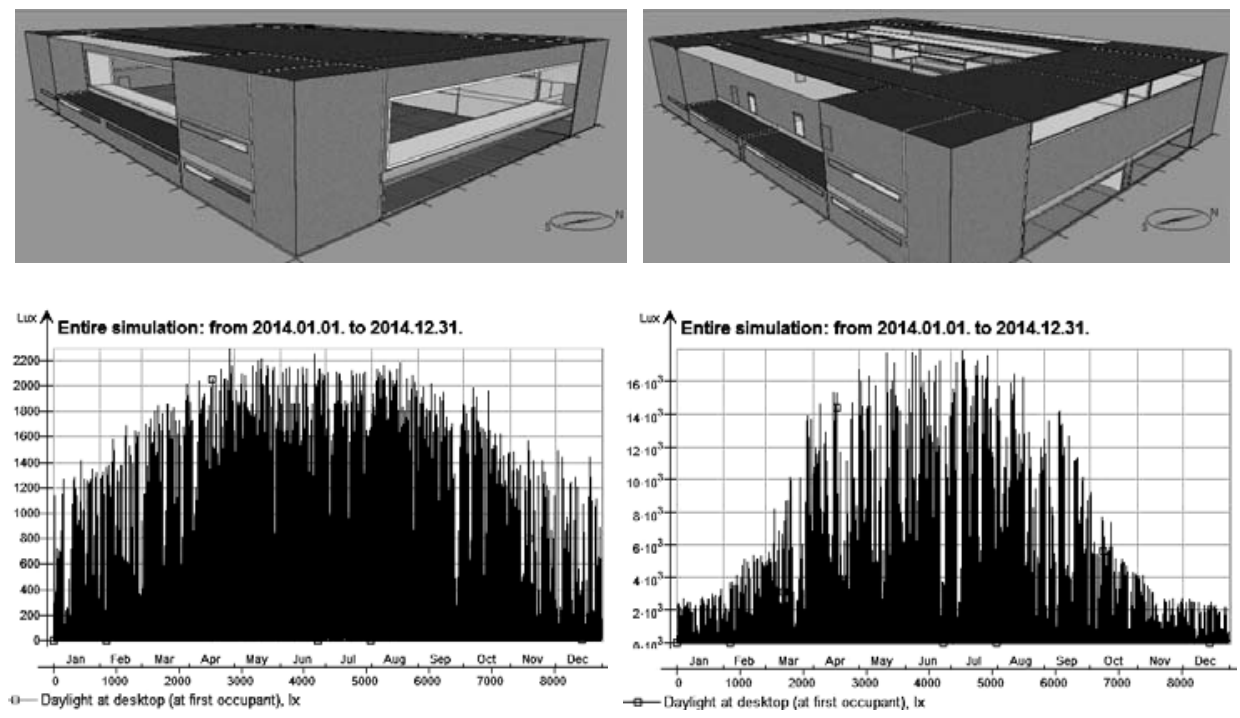

Fig. 5. Comparison of the annual (8760 h) daylight [lx] in the model with side-windows and mechanical ventilation (left side) vs. model with skylight and natural ventilation (right side)
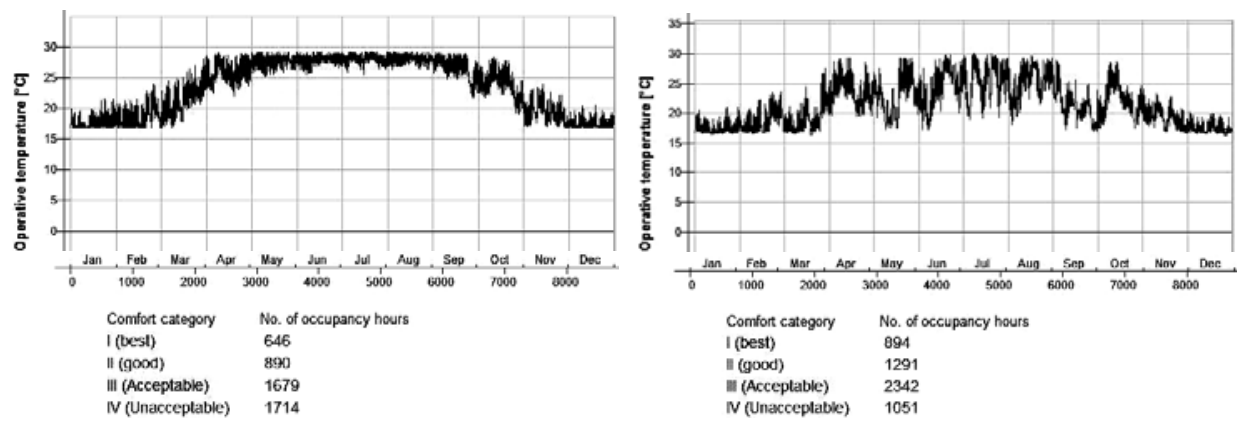

Fig. 6. Comparison of the annual $(8760 \mathrm{~h})$ climatic performance $\left[\mathrm{C}^{\circ}\right]$ of the model with side-windows and mechanical ventilation (left side) vs. model with skylight and natural ventilation (right side) 
Meanwhile the contractor specified new cost limitations, which resulted a modified plan with reduced floor area. Abandoning the 3-storey-high corner-towers resulted the central court to be emerged from the surrounding, shrunken service zones, which energetically - increased the heat-loss surface of the central court. Besides geometrical transformations the ventilation towers moved to the south perimeter of the hall (Fig. 8, Fig. 9).

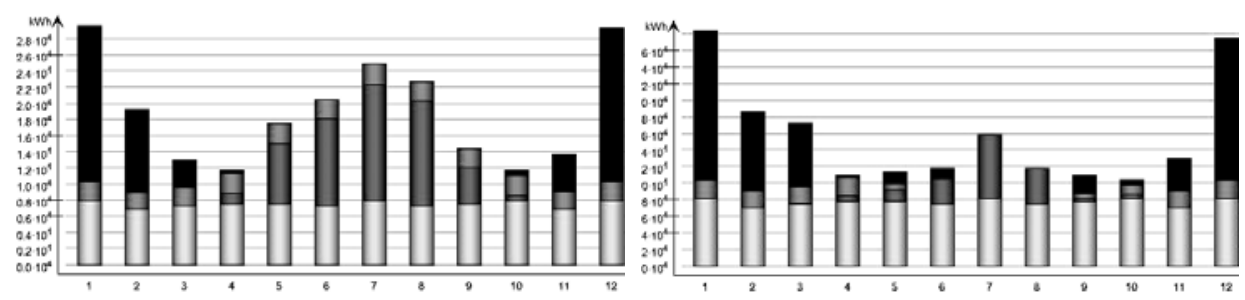

Fig. 7. Comparison of the annual $(8760 \mathrm{~h})$ energetic performance of the model with side-windows and mechanical ventilation (left side) vs. model with skylight and natural ventilation (right side) Color key: white = Lighting; light grey = HVAC; middle grey $=$ Cooling; dark grey $=$ Heating $[\mathrm{kWh}]$
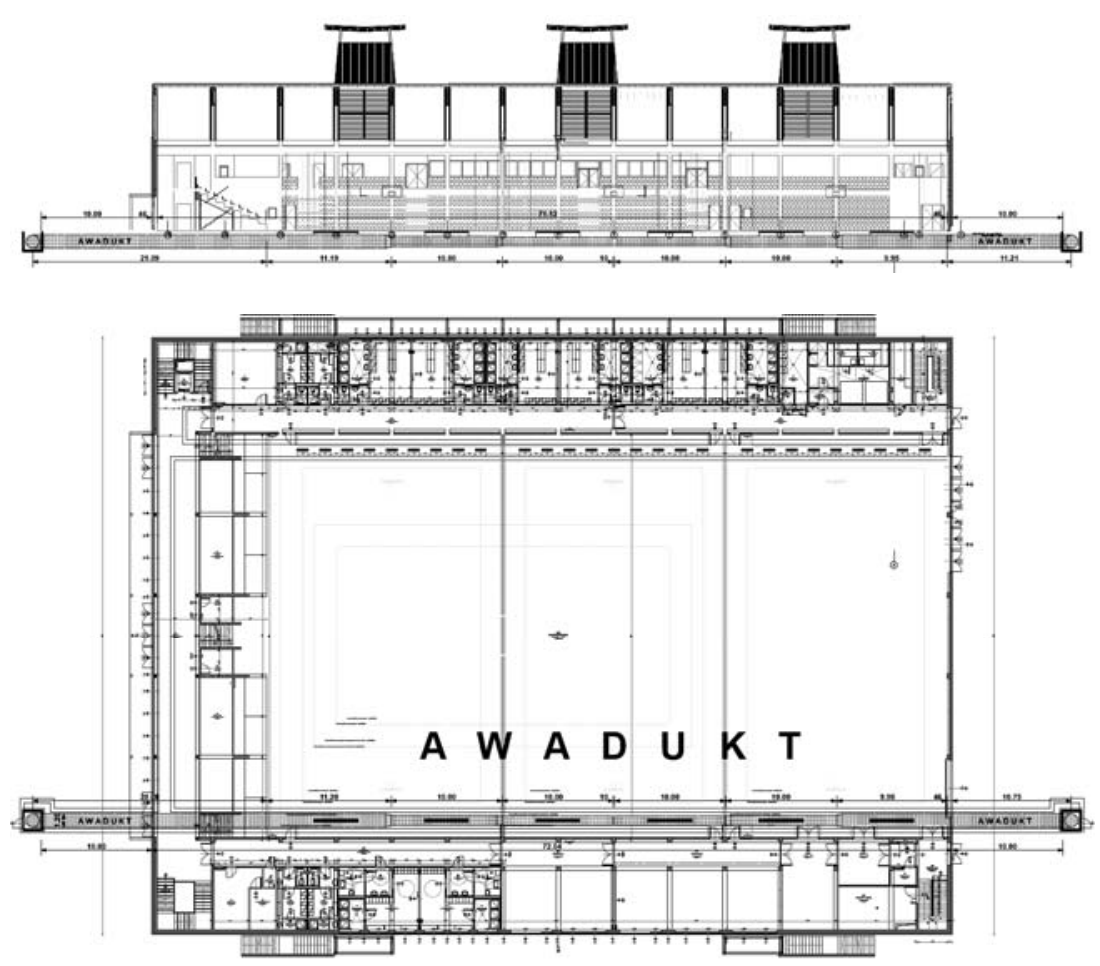

Fig. 8. The 2nd simulated model is the 3rd architectural version - floor plan 


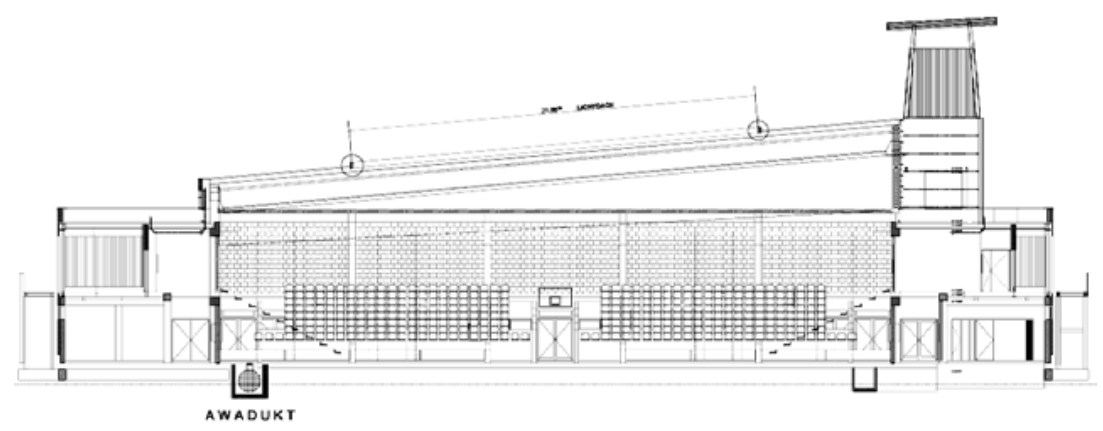

Fig. 9. The 2nd simulated model is the 3rd architectural version - cross section

The figure shown above represents the main structure elements involved in the natural ventilation concept of the project. The subterranean air duct - so called 'Awadukt' - supplies the fresh air for the sports hall in proper environmental conditions and the 3 towers let the exhausted and warm air to escape from the hall, even when the mechanical ventilation supplies the fresh air. Aerodynamic plates on top of the towers speed up the air stream and so strengthen the sucking effect inside the towers. This passive-hybrid ventilation concept is based on natural ventilation and conditioning principles of vernacular Middle-East architecture, combined with modern building technologies [3].

\section{Simulation of the architectural geometry}

The contractor's financial cut also resulted, that it had to be investigated how to convert the double layer cavity roof into a proper single layer roof meanwhile keeping the original roof-light concept with acceptable comfort and energy consumption. For comparison at this design stage the already proven double layer roofed model was taken as a reference. The energetic performance of the three investigated models could be comparable with roughly equal thermal comfort only.

The difference in cooling and heating energy demand reflects the positive heat buffer effect of the cavity roof structure. It protects the interior from the extra heat loss in the winter and from the extra heat load of the sun's radiation in the summer with natural cross ventilation of the cavity space between the inner and outer roof layers (Fig. 10 - Fig. 12).

\section{Comparison of the roof structure}

The detailed energy balance of the model variations also displays the heat buffer effect of the double layer roof, especially with a skylight. Even in comparison with a reduced cavity thickness - from 2 meters to 40 centimeters - the single layer-roofed model show double heat loss in simulation results - investigating 'Building envelope' and 'Thermal bridges' (Table I - Table II and Fig. 13 - Fig. 16), which underline the 
inevitable advantage of the double layer roof structure. Apart from all that because of the restricted financial conditions the single layer roof had to be optimized in the further design process.
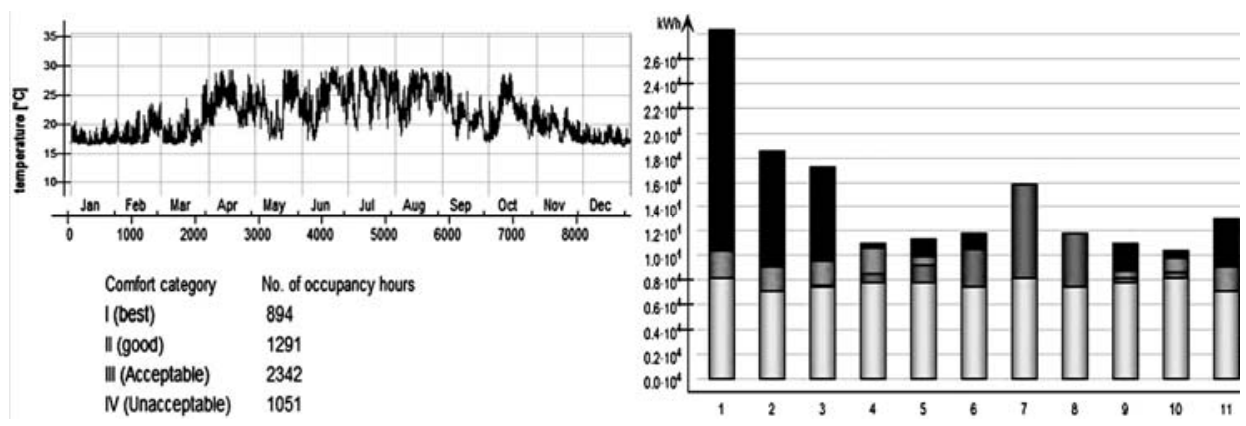

Fig. 10. The annual (8760 h) climatic and energetic performance of the original concept model Color key for diagrams: white = Lighting; light grey = HVAC; middle grey = Cooling; dark grey $=$ Heating energy $[\mathrm{kWh}]$
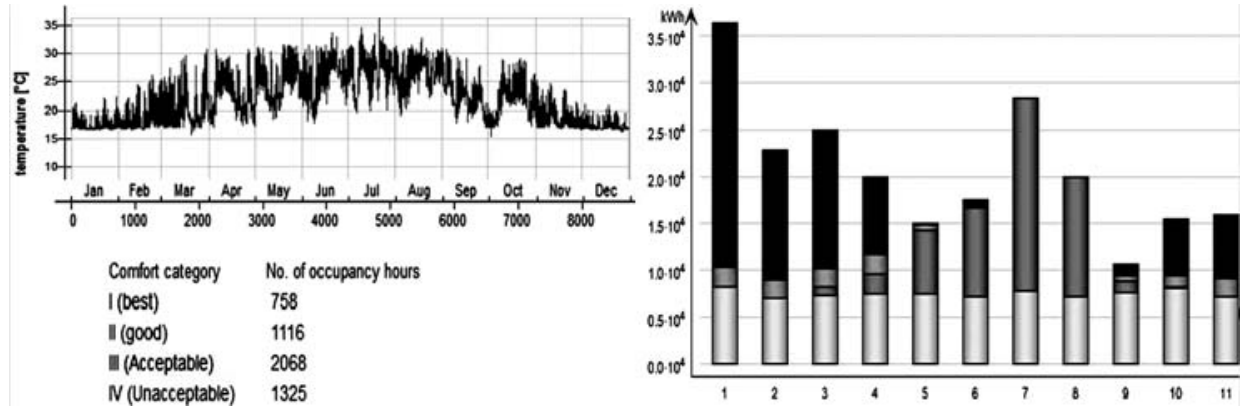

Fig. 11. The annual $(8760 \mathrm{~h})$ climatic and energetic performance of the new $3^{\text {rd }} 1$-layer model. Color key for diagrams: white = Lighting; light grey = HVAC; middle grey = Cooling; dark grey $=$ Heating energy $[\mathrm{kWh}]$
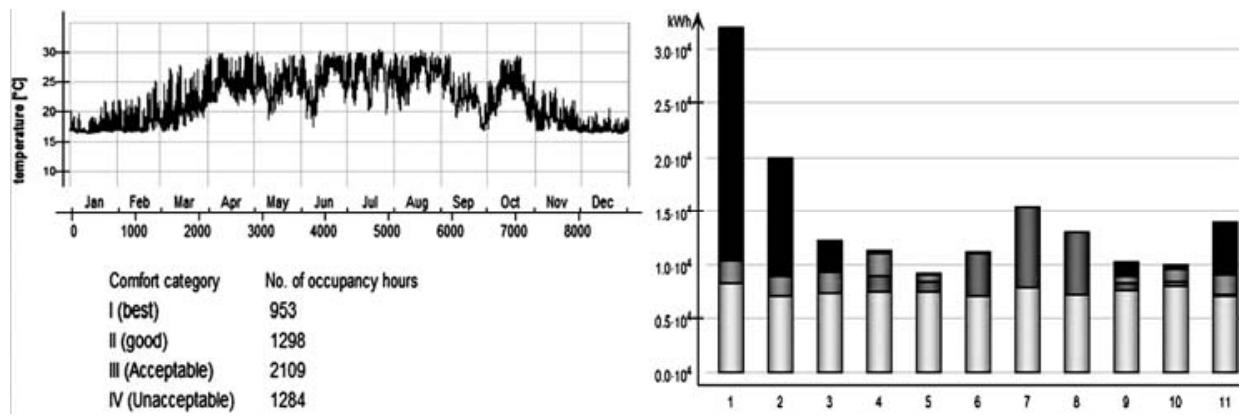

Fig. 12. The annual $(8760 \mathrm{~h})$ climatic and energetic performance of the double layer model. Color key for diagrams: white = Lighting; light grey = HVAC; middle grey = Cooling; dark grey $=$ Heating energy $[\mathrm{kWh}]$ 
Table I

The annual (8760 h) energy balance results of the hall of the 1-layer model [kWh]

\begin{tabular}{|c|c|c|c|c|c|c|c|c|c|}
\hline $\begin{array}{l}\bar{E} \\
\sum^{\circ}\end{array}$ & 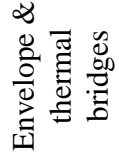 & 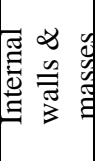 & 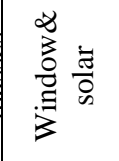 & 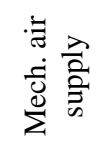 & 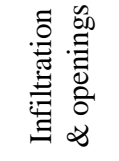 & 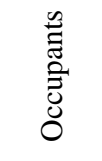 & 苛 & 플 & 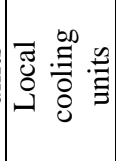 \\
\hline & 5047 & 2056 & & 1020 & 1000 & 3396 & 6266 & & \\
\hline 2 & -4284 & -1882 & $\begin{array}{l}-0540 \\
-2979\end{array}$ & -2522 & -1541 & 2726 & 5536 & 6823 & 0 \\
\hline 3 & -4343 & -1447 & 7088 & -4259 & -5486 & 2554 & 5813 & 2661 & -623 \\
\hline 4 & -3641 & -841 & 19893 & -8628 & -10246 & 1828 & 6090 & 24 & -2195 \\
\hline 5 & -1749 & -454 & 44876 & -2080 & -37673 & 1644 & 6089 & 749 & -8677 \\
\hline 6 & -1052 & 29 & 49773 & -0.1 & -39814 & 1334 & 5811 & 1759 & -15472 \\
\hline 7 & -888 & -17 & 55841 & -0.1 & -18920 & 882 & 6364 & 0 & -40171 \\
\hline 8 & -971 & 80 & 44214 & -0.1 & -22324 & 1179 & 5811 & 182 & -25055 \\
\hline 9 & -592 & 721 & 27506 & -1403 & -32923 & 2253 & 6089 & 4198 & -1532 \\
\hline 10 & -3353 & -636 & 5905 & -4030 & -4953 & 2281 & 6366 & 511 & -31 \\
\hline 11 & -3033 & -581 & -3886 & -2782 & 415 & 2714 & 5536 & 3073 & 0 \\
\hline 12 & -4492 & -2021 & -9483 & -1081 & -1656 & 3416 & 6366 & 11093 & 0 \\
\hline Total & 433.441 & 9.295 & 229.802 & 28.023 & 177.029 & 26.197 & 72.237 & 42.943 & 93.756 \\
\hline Heatil & -8580 & -1698 & -19747 & -881 & -23777 & 6633 & 12400 & 42944 & 0 \\
\hline Cooling & -5241 & -7080 & 111111 & -1966 & -8730 & 794 & 10938 & 0 & -93750 \\
\hline Rest of time & -19619 & -516 & 138438 & -25174 & -144521 & 18770 & 48898 & -0.7 & -6 \\
\hline
\end{tabular}

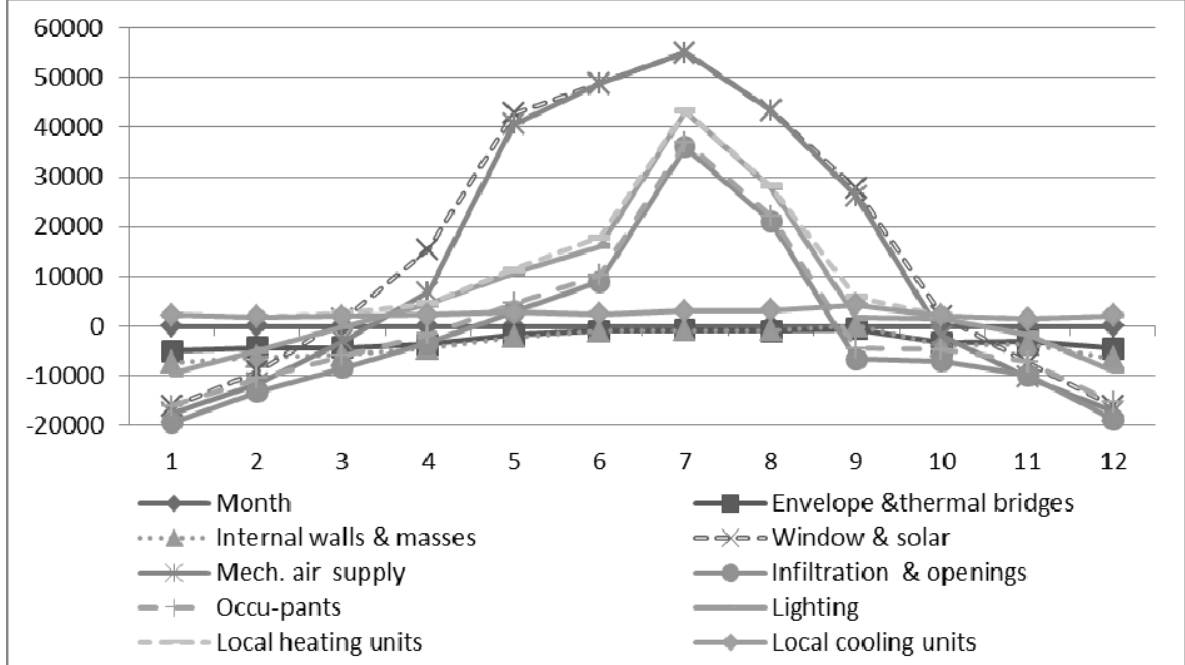

Fig. 13. The monthly energy balance results of the hall of the 1-layer model [kWh]

Pollack Periodica 11, 2016, 1 


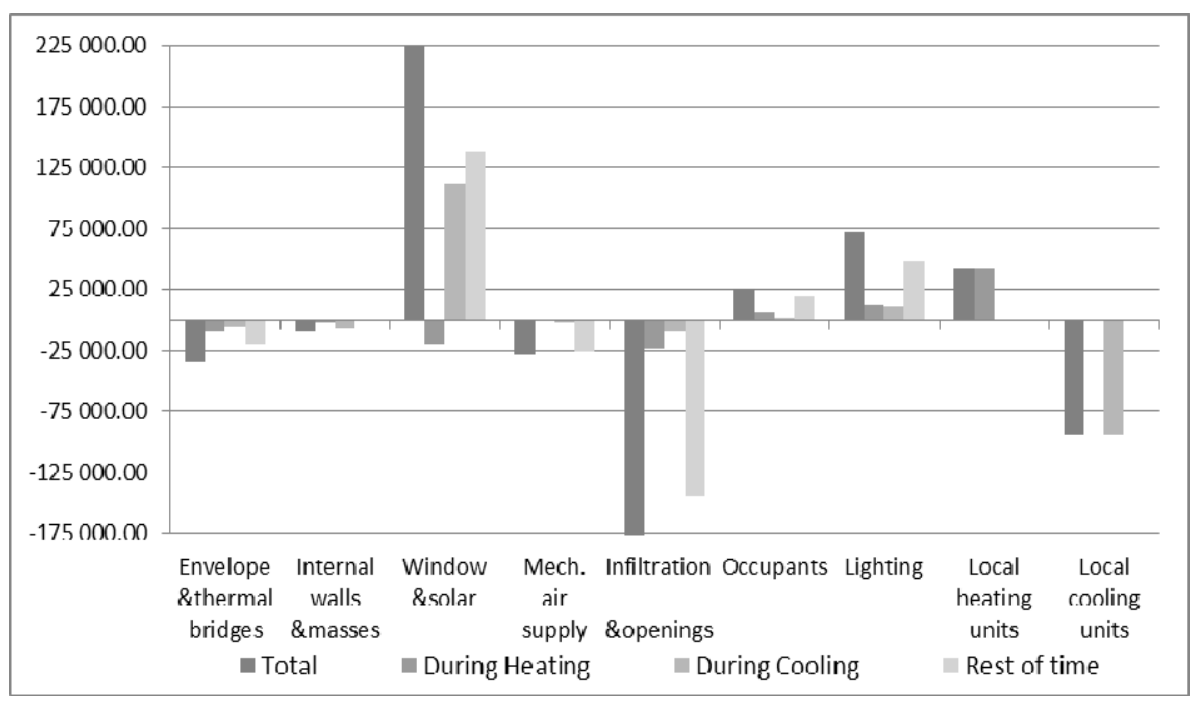

Fig. 14. The summarized energy results of the hall of the 1-layer model [kWh]

Table II

The annual (8760 h) energy balance results of the hall of the 2-layer model [kWh]

\begin{tabular}{|c|c|c|c|c|c|c|c|c|c|}
\hline 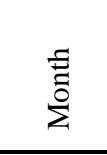 & 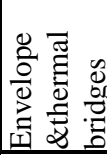 & 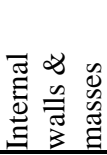 & $\begin{array}{l}\infty \\
3 \\
0 \\
0 \\
0 \\
3 \\
3 \\
3\end{array}$ & 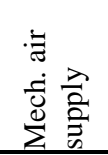 & 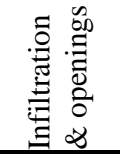 & 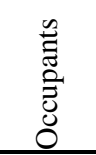 & 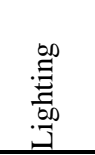 & శ్ర్ర & ד్రే: \\
\hline 1 & -1181 & -4190 & -2989 & -2173 & -5450 & 3337 & 6367 & 7952 & 0 \\
\hline 2 & -1362 & -3264 & 2369 & -3598 & -4181 & 2656 & 5536 & 3234 & 0 \\
\hline 3 & -2112 & -3520 & 11605 & -8293 & -3427 & 2012 & 5813 & 172 & -708 \\
\hline 4 & -2327 & -2935 & 22682 & -12907 & -461 & 1146 & 6090 & 0 & -9783 \\
\hline 5 & -1374 & 4 & 40099 & -2238 & -41871 & 2076 & 6089 & 356 & -668 \\
\hline 6 & -1449 & 361 & 42434 & -0 & -37978 & 1735 & 5811 & 1209 & -10119 \\
\hline 7 & -1564 & 474 & 46179 & -0 & -28519 & 1622 & 6364 & 0 & -21954 \\
\hline 8 & -1489 & 332 & 41261 & -0 & -29139 & 1497 & 5811 & 0 & -15237 \\
\hline 9 & -357 & 635 & 27533 & -1326 & -35977 & 2560 & 6089 & 5765 & -1048 \\
\hline 10 & -1739 & -2684 & 7479 & -5230 & -2434 & 1822 & 6367 & 0 & -2320 \\
\hline 11 & -537 & -2046 & 681 & -4076 & -1887 & 2616 & 5536 & 868 & 0 \\
\hline 12 & -867 & -4020 & -4508 & -1564 & -5284 & 3421 & 6366 & 8085 & 0 \\
\hline Total & $\begin{array}{l}-16.359 \\
\end{array}$ & -20.851 & 234.825 & -41.405 & -196.608 & 26.500 & 72.239 & 27.643 & -61.837 \\
\hline Heating & 2031 & -4630 & -7836 & -614 & -23527 & 3816 & 6908 & 27641 & 0 \\
\hline Cooling & -8966 & -8544 & 94361 & -11186 & -14597 & 1906 & 13508 & 0 & -61833 \\
\hline $\begin{array}{l}\text { Rest of } \\
\text { time }\end{array}$ & -9424 & -7676 & 148300 & -29604 & -158483 & 20777 & 51822 & 1 & -3 \\
\hline
\end{tabular}




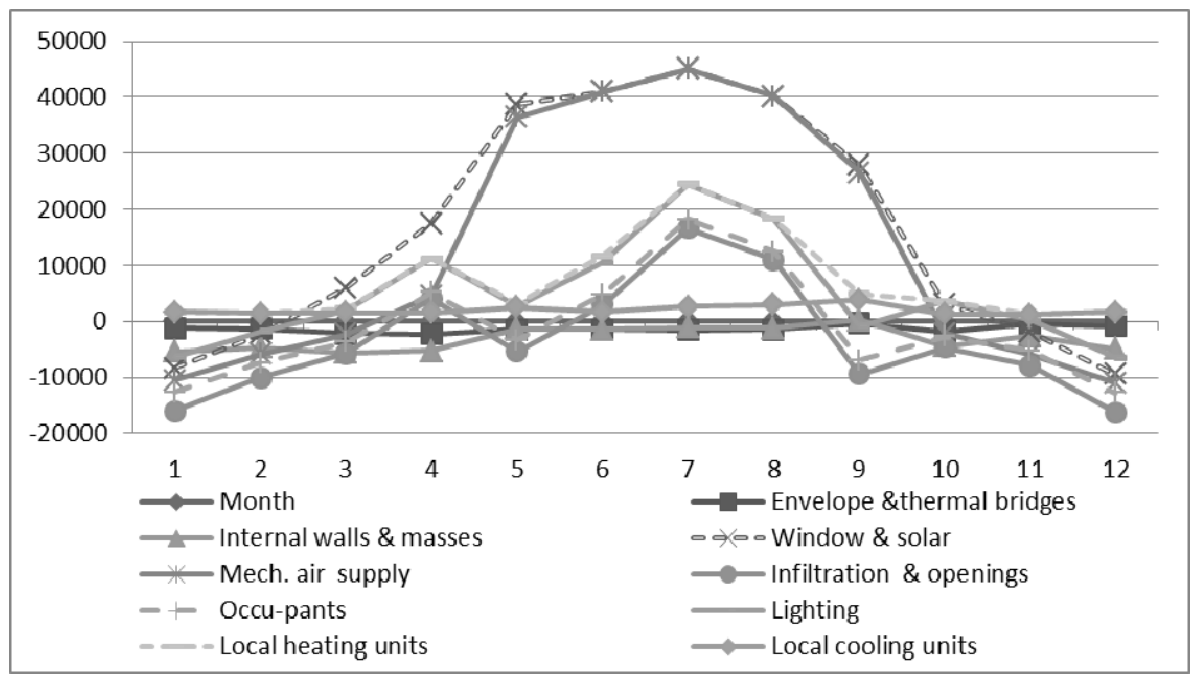

15. The monthly energy balance results of the hall of the 2-layer model [kWh]

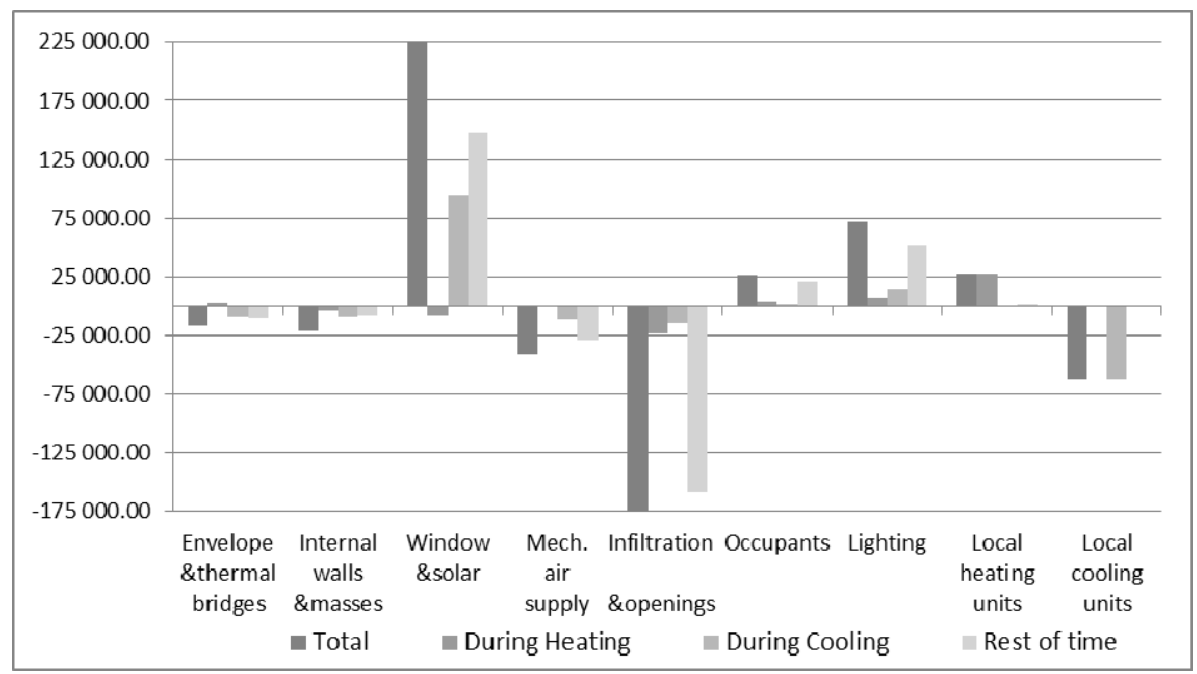

Fig. 16. The summarized energy results of the hall of the 2-layer model [kWh]

\section{Analysis of the temperature control}

Until that design stage, the temperature control range of the main court based by the appointment with the mechanical engineers and kept within $17-28{ }^{\circ} \mathrm{C}$ to keep the energy consumption at a low level.

After a while the project strategy turned into preferring to meet the FIBA (International Basketball Federation) standard requirements, which meant that the

Pollack Periodica 11, 2016, 1 
temperature in the hall must be kept within $18-25{ }^{\circ} \mathrm{C}$. The effect of the modified temperature control range to the energy demand of the actual model variation had to be investigated.

It was inevitable, that the thermal comfort increased in the model with narrower temperature limitation, culminating in less overheating days in the summer. But, of course it had its cost in energy. The $3{ }^{\circ} \mathrm{C}$ reduction in summer resulted more than 2.5times more cooling energy, although the $1{ }^{\circ} \mathrm{C}$ upgrade in winter needed only $4 \%$ more heating (Table III and Fig. 17).

\section{Table III}

Comparison of the energetic performance of the final model with different temperature controls: $17-28^{\circ}$ vs. $18-25^{\circ} \mathrm{C}$

\begin{tabular}{|c|c|c|c|c|c|c|c|}
\hline & \multicolumn{2}{|c|}{ Delivered energy } & \multirow{2}{*}{$\frac{\text { Demand }}{\mathrm{kW}}$} & \multicolumn{2}{|c|}{$\mathrm{CO}_{2}$} & \multicolumn{2}{|c|}{ Primary energy } \\
\hline & kWh & $\mathrm{kWh} / \mathrm{m}^{2}$ & & kg & $\mathrm{kg} / \mathrm{m}^{2}$ & kWh & $\mathrm{kWh} / \mathrm{m}^{2}$ \\
\hline $\begin{array}{l}\text { Lighting, } \\
\text { facility }\end{array}$ & 91746 & 13 & 312 & 33487 & 4 & 229365 & 32 \\
\hline $\begin{array}{l}\text { Electric } \\
\text { cooling }\end{array}$ & 22191 & 3 & 159 & 8100 & 1 & 55478 & 7 \\
\hline $\begin{array}{l}\text { HVAC } \\
\text { aux }\end{array}$ & 14870 & 2 & 108 & 5427 & 0 & 37174 & 5 \\
\hline $\begin{array}{l}\text { Total, } \\
\text { Facility } \\
\text { electric }\end{array}$ & 128807 & 18 & & 47014 & 6 & 322017 & 45 \\
\hline District & 88275 & 12 & 236 & 32220 & 4 & 220688 & 31 \\
\hline $\begin{array}{l}\text { Total, } \\
\text { Facility } \\
\text { district }\end{array}$ & 88275 & 12 & & 32220 & 4 & 220688 & 31 \\
\hline Total & 217082 & 30 & & 79234 & 11 & 542705 & 76 \\
\hline
\end{tabular}

\begin{tabular}{|c|c|c|c|c|c|c|c|}
\hline & \multicolumn{2}{|c|}{ Delivered energy } & \multirow{2}{*}{$\begin{array}{c}\text { Demand } \\
\mathrm{kW}\end{array}$} & \multicolumn{2}{|c|}{$\mathrm{CO}_{2}$} & \multicolumn{2}{|c|}{ Primary energy } \\
\hline & kWh & $\mathrm{kWh} / \mathrm{m}^{2}$ & & $\mathrm{~kg}$ & $\mathrm{~kg} / \mathrm{m}^{2}$ & kWh & $\mathrm{kWh} / \mathrm{m}^{2}$ \\
\hline $\begin{array}{l}\text { Lighting, } \\
\text { facility }\end{array}$ & 91926 & 13 & 312 & 33443 & 4 & 229065 & 32 \\
\hline $\begin{array}{l}\text { Electric } \\
\text { cooling }\end{array}$ & 51983 & 7 & 157 & 18974 & 2 & 129956 & 18 \\
\hline $\begin{array}{l}\text { HVAC } \\
\text { aux }\end{array}$ & 14867 & 2 & 108 & 5426 & 0 & 37167 & 5 \\
\hline $\begin{array}{l}\text { Total, } \\
\text { Facility } \\
\text { electric }\end{array}$ & 158476 & 22 & & 57843 & 8 & 396188 & 56 \\
\hline $\begin{array}{l}\text { District } \\
\text { heating }\end{array}$ & 90738 & 12 & 230 & 33119 & 4 & 226844 & 32 \\
\hline $\begin{array}{l}\text { Total, } \\
\text { Facility } \\
\text { district }\end{array}$ & 90738 & 12 & & 33119 & 4 & 226844 & 32 \\
\hline Total & 249214 & 35 & & 90962 & 12 & 623032 & 88 \\
\hline
\end{tabular}



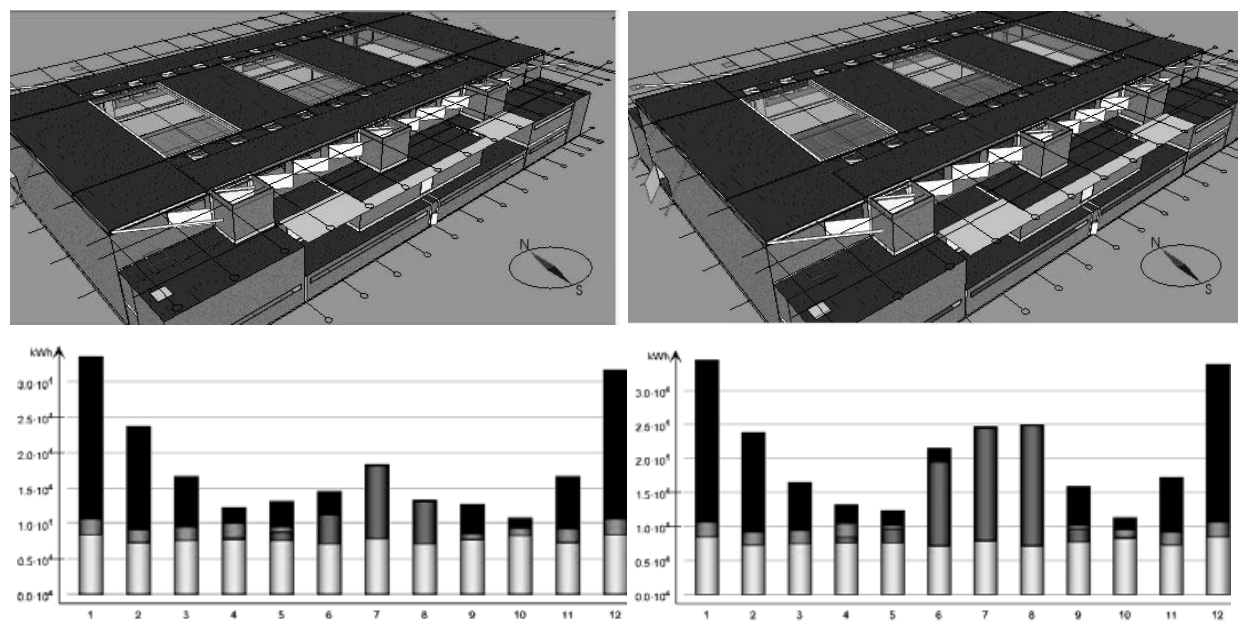

Fig. 17. Comparison of the annual $(8760 \mathrm{~h})$ energetic performance of the final model with different temperature controls: $17-28^{\circ} \mathrm{C}$ (left) vs. $18-25^{\circ} \mathrm{C}$ (right).

Color key: white $=$ Lighting; light grey $=$ HVAC; middle grey = Cooling; dark grey $=$ Heating energy $[\mathrm{kWh}]$

\section{Investigation of the natural ventilation concept}

At the stage of the construction plan the extra limited financial framework of the project resulted simplifications in the building: after deleting the double layer roof the roof-light had to be shrunken in size. Nevertheless, the payback potential of the whole natural ventilation system also had to be validated, meaning that the cost efficiency of the under-floor air supply pipe system, the ventilation towers, the motorized ventilation shutters and all the structures relating to the system had to be under investigation.

For comparison the final single layer roof model - with almost half size polycarbonate skylight - was taken. The architect designers had to divide the reduced (600 m2) skylight into 3 parts to keep the proper ad equal illumination on the 3 basketball courts.

The final model was simulated with two different settings, one with solely mechanical ventilation all year long with heating in the winter and with cooling in the summer, the other with mechanical ventilation and with heating in the winter and a combination of natural (supply+exhaust) and mechanical (only supply) ventilation and with cooling from April to September.

First, the thermal comfort level of the two model variations had to be equalized to make the energy performances comparable. The naturally ventilated model had a huge advantage in the summer by using only quarter of cooling energy than the mechanical ventilated model. The energy demand for ventilating implicitly also higher in the 'artificial' model, the difference is twofold. However in the heating energy consumption the mechanical model is the winner by $25 \%$. Not counting the energy used for artificial lighting the summarized energy balance shows a $31 \%$ advantage of the naturally ventilated model (Fig. 18-Fig. 19 and Table IV-Table V).

Pollack Periodica 11, 2016, 1 

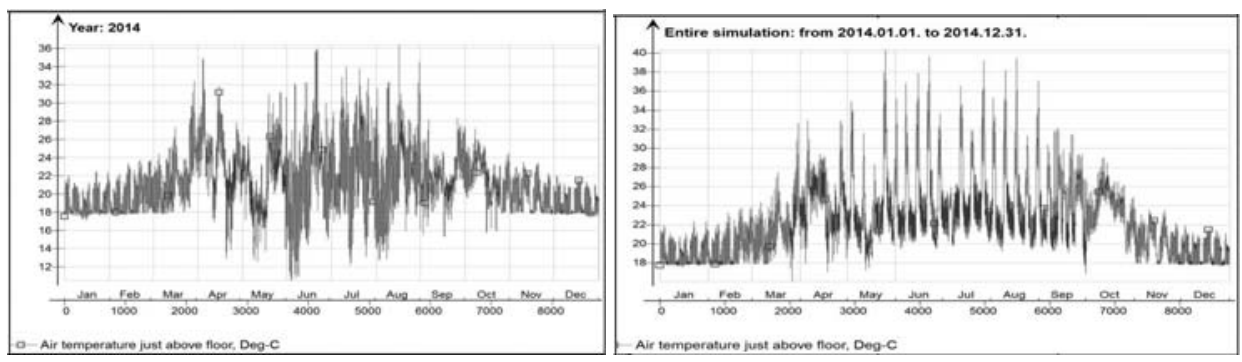

Fig. 18. Comparison of the annual $(8760 \mathrm{~h})$ climatic performance of the final model variations, combination of natural and mechanical (left) vs. solely mechanical ventilation (right) $\left[\mathrm{C}^{\mathrm{o}}\right]$

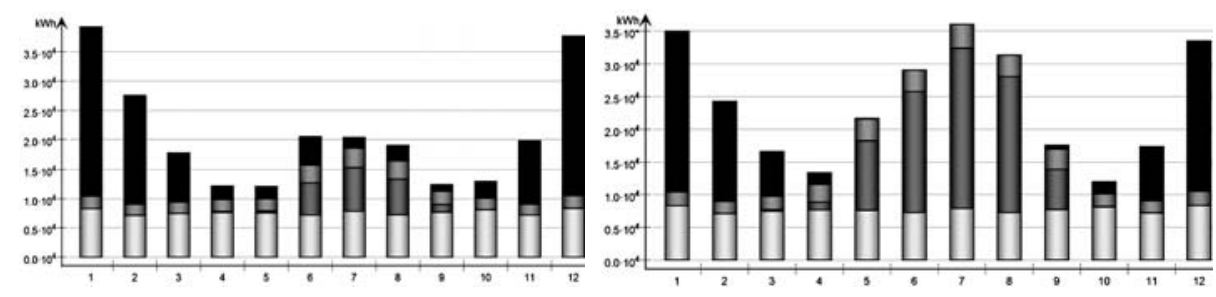

Fig. 19. Comparison of the annual (8760 h)energetic performance of the final model variations, combination of the natural and mechanical ventilation (left) vs. solely mechanical ventilation (right) [kWh]

\section{Table IV}

Comparison of the climatic performance of the final model variations, combination of natural and mechanical ventilation (left) vs. solely mechanical ventilation (right)

\begin{tabular}{|c|c|c|c|}
\hline $\begin{array}{l}\text { Days, when the temperature } \\
\text { is reaching or above } 30 \mathrm{C}^{\circ}\end{array}$ & 9 days & $\begin{array}{l}\text { Hours, when thermal comfort } \\
\text { is unsatisfactory }\end{array}$ & $\begin{array}{c}879 \\
\text { hours }\end{array}$ \\
\hline $\begin{array}{l}\text { Days, when the temperature } \\
\text { is reaching or above } 28 \mathrm{C}^{\circ}\end{array}$ & 35 days & $\begin{array}{l}\text { Days, when the temperature } \\
\text { is reaching or above } 30 \mathrm{C}^{\circ}\end{array}$ & 10 days \\
\hline $\begin{array}{l}\text { Days, when the temperature } \\
\text { is above } 25 C^{0}\end{array}$ & 74 days & $\begin{array}{l}\text { Days, when the temperature } \\
\text { is reaching or above } 28 \mathrm{C}^{\circ}\end{array}$ & 26 days \\
\hline $\begin{array}{l}\text { Days, when the temperature } \\
\text { is below } 18 \mathrm{C}^{0}\end{array}$ & 22 days & $\begin{array}{l}\text { Days, when the temperature } \\
\text { is above } 25 \mathrm{C}^{\circ}\end{array}$ & 79 days \\
\hline $\begin{array}{l}\text { Days, when the temperature } \\
\text { is below } 18 C^{0} \& \text { above } 25 C^{0}\end{array}$ & 96 days & $\begin{array}{l}\text { Days, when the temperature } \\
\text { is below } 18 \mathrm{C}^{\circ}\end{array}$ & 6 days \\
\hline $\begin{array}{l}\text { Days, when the temperature } \\
\text { is below } 18 C^{0} \& \text { above } 25 C^{0}\end{array}$ & 85 days & $\begin{array}{l}\text { Hours, when thermal comfort } \\
\text { is unsatisfactory }\end{array}$ & $\begin{array}{c}564 \\
\text { hours }\end{array}$ \\
\hline
\end{tabular}

Counting altogether, in total final energy consumption the advantage is still almost $20 \%$, for the benefit of the naturally ventilated model which means that to build the elements of the natural ventilation system paybacks itself in 17 years from financial point of view (calculated with current Hungarian fee of electricity, which will inevitably increase in time). 
Table V

Comparison of the energetic performance of the final model variations, combination of a) the natural and mechanical ventilation vs. b) solely mechanical ventilation

a)

\begin{tabular}{|c|c|c|c|c|}
\hline $\begin{array}{c}\text { Cooling } \\
\text { (KWh/a) }\end{array}$ & $\begin{array}{c}\text { Heating } \\
\text { (KWh/a) }\end{array}$ & $\begin{array}{c}\text { HVAC } \\
\text { (KWh/a) }\end{array}$ & $\begin{array}{c}\text { Lighting } \\
\text { (KWh/a) }\end{array}$ & $\begin{array}{c}\text { Total E } \\
\text { (KWh/a) } \\
2097\end{array}$ \\
110918 & 17982 & 91812 & 241619 \\
$100 \%$ & $100 \%$ \\
\hline \multicolumn{5}{|l|}{ PRIMARY ENERGY } \\
\hline 52268 & 277295 & 44955 & 229530 & 604048 \\
& 374518 & $100 \%$ & $100 \%$ \\
\hline
\end{tabular}

b)

\begin{tabular}{|c|c|c|c|c|}
\hline $\begin{array}{c}\text { Cooling } \\
\text { (KWh/a) } \\
82117\end{array}$ & $\begin{array}{c}\text { Heating } \\
\text { (KWh/a) } \\
82500\end{array}$ & $\begin{array}{l}\text { HVAC } \\
\text { (KWh/a) } \\
31406 \\
196023\end{array}$ & $\begin{array}{c}\text { Lighting } \\
\text { (KWh/a) } \\
92006 \\
131 \%\end{array}$ & $\begin{array}{c}\text { Total E } \\
\text { (KWh/a) } \\
288029 \\
119 \%\end{array}$ \\
\hline \multicolumn{5}{|c|}{ PRIMARY ENERGY } \\
\hline 205293 & 206250 & $\begin{array}{r}78515 \\
\quad 374518\end{array}$ & $\begin{array}{c}230015 \\
131 \%\end{array}$ & $\begin{array}{c}720073 \\
119 \%\end{array}$ \\
\hline
\end{tabular}

It has to be remarked that besides energetic and climatic simulations, aerodynamic and light simulations were also being investigated maximizing the use of the natural resources as natural light and natural ventilation. An efficient natural ventilation concept, including three exhaust ventilation wind towers, was examined by creating a CFD (computational fluid dynamics) building model for air flow simulations. This modeling process was carried out by defining a finite volume $3 \mathrm{~d}$ mesh in similar way to former investigations [4].

\section{Conclusion}

The energy savings potential of using natural lighting and natural ventilation and/or cavity structures - façade and/or roof - in public buildings is undoubtedly proven prior to the above investigated simulation procedure.

The designing process supported with dynamic energy and climate building simulations could count for the whole national economy by reducing energy consumption not only for certain buildings but for cities as well. Helping to elaborate energy and optimization strategies of the built environment, it could drastically reduce the energy dependence and as a result of it the $\mathrm{CO}_{2}$ emission of the country. This would help not only to save our environment, but it could increase the economic potential of our country. 


\section{References}

[1] Hensen J. L. M., Lamberts R. (Ed.) Building performance simulation for design and operation, Spon Press, 2011, pp. 84-142.

[2] Baranyai B. , Kistelegdi I. Energy management monitoring and control of public buildings, Pollack Periodica, Vol. 9, No. 2, 2014, pp. 77-88.

[3] Hindrichs D. U., Daniels K. Plusminus $20^{\circ} / 40^{\circ}$ latitude, Edition Axel Menges, 2007, pp. 164-189.

[4] Kistelegdi I., Háber I. Building aerodynamic investigations for an energy-plus production facility in Sikonda (Hungary), Bauphysik, Vol. 34, No. 3, 2012, pp. 107-120. 